Article

\title{
New Environmentally Friendly Acid System for Iron Sulfide Scale Removal
}

\author{
Hany Gamal, Khaled Abdelgawad $(1)$ and Salaheldin Elkatatny *(i) \\ College of Petroleum Engineering and Geosciences, King Fahd University of Petroleum \& Minerals, \\ 31261 Dhahran, Saudi Arabia; g201706870@kfupm.edu.sa (H.G.); abouzidan@kfupm.edu.sa (K.A.) \\ * Correspondence: elkatatny@kfupm.edu.sa; Tel.: +966-594-663-692
}

Received: 31 October 2019; Accepted: 26 November 2019; Published: 27 November 2019

\begin{abstract}
Iron sulfide scale is a common problem in the oil and gas industry. The precipitation of the iron sulfide scale on the well completion tools or inside surface flow lines restricts the flow of the produced fluids and might affect the integrity of the pipelines or the surface and subsurface tools. Failure of the downhole completions tools will not only reduce the production rates but it might require workover and remedial operations that will add extra cost. The main objective of this paper is to evaluate a new environmentally friendly acid system (NEFAS) for iron sulfide scale removal using an actual field sample. The scale sample collected from a natural gas well is dominated by pyrrhotite $(55 \%)$ in addition to calcite $(21 \%)$, pyrite $(8 \%)$, and torilite $(6 \%)$ with minor traces of hibbingite, siderite, geothite, akaganeite, and mackinawite. High-temperature solubility tests were performed by soaking $2 \mathrm{~g}$ of the scale field sample with $20 \mathrm{~cm}^{3}$ of the NEFAS under static condition at $125^{\circ} \mathrm{C}$ for different time periods $(2,6,12,18$, and $24 \mathrm{~h})$. The solubility results were compared with commercial solutions for iron sulfide scale removal such as hydrochloric acid (15 wt.\%), glutamic acid diacetic acid (GLDA, $20 \mathrm{wt} . \%$ ), and high density converters (HDC-3) under the same conditions. The corrosion test was performed at $125^{\circ} \mathrm{C}$ for the developed solution after mixing with $2 \mathrm{wt} . \%$ corrosion inhibitor (CI) and $2 \mathrm{wt} . \%$ corrosion intensifier (CIN). The results were compared with $\mathrm{HCl}(15 \mathrm{wt} . \%)$ under the same conditions. NEFAS consists of $75 \mathrm{wt} . \%$ biodegradable acid at $\mathrm{pH}$ of 0.04 . NEFAS achieved $83 \mathrm{~g} / \mathrm{L}$ solubility of iron sulfide scale after $6 \mathrm{~h}$ at $125^{\circ} \mathrm{C}$ under static conditions. The solubility efficiency was very close to $15 \mathrm{wt} . \% \mathrm{HCl}$ after $24 \mathrm{~h}$ where the solubility was 82 and $83 \mathrm{~g} / \mathrm{L}$ for NEFAS and $\mathrm{HCl}$, respectability. HDC-3 and GLDA (20 wt.\%) achieved a lower scale solubility; $18 \mathrm{~g} / \mathrm{L}$ and $65 \mathrm{~g} / \mathrm{L}$ respectively, after $24 \mathrm{~h}$. NEFAS achieved a corrosion rate of $0.211 \mathrm{~kg} / \mathrm{m}^{2}$ after adding the CI and and CIN compared to $0.808 \mathrm{~kg} / \mathrm{m}^{2}$ for $\mathrm{HCl}$. The new environmentally friendly biodegradable acid system provides efficient performance for the scale removal without harming the environment and causing any side effects to the operation.
\end{abstract}

Keywords: iron sulfide; scale removal; biodegradable acid; environmentally friendly; corrosion rate

\section{Introduction}

Iron sulfide scale is one of the major problems of flow assurance in the oil and gas industry. Iron sulfide scale is formed because of the presence of iron and hydrogen sulfide in sour oil and gas production wells. Iron sulfide scale usually causes many operational problems in the oil and gas industry as it accumulates in perforations, downhole tubing equipment, surface flow lines, and even inside the pore space of the reservoir rock itself [1-3]. The formation of iron sulfide scale can affect the performance of downhole tools such as artificial lift equipment. In addition, iron sulfide scale usually interferes with the safe operation of pipeline valving systems and rapidly erodes surface chokes because of the high erosion rate when it flows with the produced gas stream [4-6]. 
Iron sulfide depositions have an adverse influence on production and injection operations. The precipitation of the iron sulfide scale in the near-wellbore can diminish the productivity of the production wells [4], and also can cause loss of the injectivity in water injection wells [6-8].

Iron sulfide scale exists in several forms with troilite $(\mathrm{FeS})$ and pyrite $\left(\mathrm{FeS}_{2}\right)$ as the most common types based on how rich the scales are in sulfur and ferric ions [5,9]. Iron sulfide scale type depends on the range of temperatures and the scale age. The scale materializes in a crystalline form having different ratios of sulfur to iron. The different forms of iron sulfide scale are: pyrrhotite $\left(\mathrm{Fe}_{7} \mathrm{~S}_{8}\right)$, troilite (FeS), marcasite $\left(\mathrm{FeS}_{2}\right)$, pyrite $\left(\mathrm{FeS}_{2}\right)$, greigite $\left(\mathrm{Fe}_{2} \mathrm{~S}_{4}\right)$, and mackinawite $\left(\mathrm{Fe}_{9} \mathrm{~S}_{8}\right)[5,9]$. Several types of iron sulfide scale might exist in the same well. Usually hard or insoluble scales exist at shallower depths compared to the soft or soluble scales [10]. Using $\mathrm{HCl}$ cannot remove all the existing forms of iron sulfide in the same well because it can remove FeS, but it cannot remove the $\mathrm{FeS}_{2}$ [11]. Therefore, both chemical and mechanical treatments are used in such cases.

Various sources deliver hydrogen sulfide and iron during different operational processes. Commonly in sour gas wells, hydrogen sulfide can be produced as free gas. Hydrogen sulfide is also produced due to water injection containing high sulfate content. The source of hydrogen sulfide might be sulfate-reducing bacteria (SRB), sulfur reduction by thermo-chemical interactions, thermal degradation of the organic sulfur compound, and using acid treatment of deep sour well [1,12]. The other component of iron sulfide scale is the iron that is produced either from the formation brine or by the corrosion of the tubing which is controlled by using effective corrosion inhibitors [6]. Iron can be introduced into the formation during acidizing with iron from the corroded tank surfaces or from the corroded well tubular. This will cause iron scale deposits in the formation or in the wellbore. Well stimulation acids can dissolve rust of storage tanks which contains a mixture of iron (II) and iron (III) [13]. Iron-containing minerals in the formation represent other iron sources such as chlorite clay mineral, iron carbonate compounds, etc. Iron compounds that precipitate during well stimulation can badly decrease the permeability of the reservoir [9].

Iron sulfide scale materializes in a crystalline form having different ratios of sulfur to iron. The sulfur to iron ration is one of the unique properties which distinguish different forms of iron sulfide. This disparity encourages experts for deep investigation and understating of these properties to develop proper treatments to remove or mitigate this kind of scale. The physical state of iron sulfide scale may vary from viscous black fluid to dry black powder. The physical and chemical properties of iron sulfide scale are function of many factors as temperature, pressure, scale age, and $\mathrm{pH}$. Iron is usually present in a +2 or +3 oxidation state. At equilibrium conditions, all the iron is present in +3 oxidation state and it happens usually in the surface facilities. At normal reservoir conditions, iron is present in $a+2$ oxidation state. Based on the analysis of different field samples, it was observed that the ratio of iron (II) to iron (III) is 5:1 $[9,14,15]$. However, that ratio can vary in different wells and formations. A typical iron sulfide scales deposit is shown in Figure 1. Black powders are known in the industry as admixture of iron sulfide and other iron scales including iron oxide and iron carbonate chemically or mechanically mixed with salts, sand, liquid hydrocarbons, or metal debris [16].

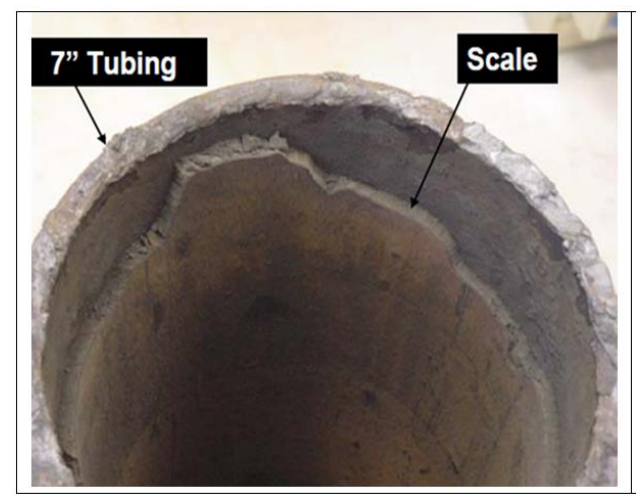

Figure 1. Typical iron sulfide scales in pipelines [6]. 


\section{Iron Sulfide Scale Removal}

There are several chemicals that are being used to remove iron sulfide scales. Such chemicals include hydrochloric and organic acids, acrolein, tetrakis (hydroxymethyl) phosphonium salts (THPS), and chelating agents (sequestrants). Generally, the iron sulfide scale is soluble in hydrochloric acid and organic acids as formic acid (HCOOH) [6]. When the iron scale depositions contain low sulfur content, it would have a higher degree of solubility in $\mathrm{HCl}$ acid [17]. Leal et al. [18] reported that pyrite and marcasite iron sulfides are acid-insoluble, pyrrhotite showed a slow pace solubility, while mackinawite and trolite are highly soluble in low pH DPTA with $5 \mathrm{wt} . \% \mathrm{HCl}$. Lawson [19] showed that maleic acid was supposed to be one of the ferrous sulfide dissolvers with minimal production of $\mathrm{H}_{2} \mathrm{~S}$.

Wang et al. [10] concluded that $\mathrm{HCl}$ can be used to remove the soft type of iron sulfide scale (FeS). The major problem of using $\mathrm{HCl}$ to remove soft scale is the high corrosion rate, especially at high temperatures. In addition, acid dissolution reaction generates a large amount of $\mathrm{H}_{2} \mathrm{~S}$ gas which can be a serious issue for well integrity and can increase the operational risk at surface facilities [3]. $\mathrm{HCl}$ also has a corrosion effect and, therefore, the removal formulation should include a corrosion inhibitor. On the other hand, using corrosion inhibitors resulted in decreasing the dissolution rate of iron sulfide while using the surfactants increasing the dissolution rate [20]. Mutual solvents such as monobutyl glycol ether were useful as it removed the hydrocarbons exist on the surface of the iron sulfide scale [21]. The reaction of hydrochloric acid $\mathrm{HCl}$ with iron sulfide produces the toxic $\mathrm{H}_{2} \mathrm{~S}$ gas as indicated by Equation (1), therefore, $\mathrm{H}_{2} \mathrm{~S}$ scavenger has to be added to the removal formulation to remove the $\mathrm{H}_{2} \mathrm{~S}$ [22]:

$$
\mathrm{FeS}+2 \mathrm{HCl} \rightarrow \mathrm{Fe}^{+2}+2 \mathrm{Cl}^{-1}+\mathrm{H}_{2} \mathrm{~S} .
$$

Sulfide scavengers which are aldehyde-based cause a reduction in the dissolution rate of iron sulfide because of the polymer deposition on the scale surface. However, triazine scavengers could be used as an alternative. A possibility for forming insoluble iron salts as a result of the increase in $\mathrm{pH}$ due to getting the $\mathrm{HCl}$ acid spends. Therefore, to prevent that, an iron control agent as citric acid or any chelating agent should be added [23]. Conversely, adding the citric acid to $\mathrm{HCl}$ reduces the dissolution of iron sulfide scale in $\mathrm{HCl}$ [2]. Using other chelates such as ethylenediaminetetraacetic acid (EDTA) will possibly have the same reduction effect for the iron sulfide dissolution rate. Mahmoud et al. [24,25] introduced a new formulation that can be used to remove pyrite iron sulfide scale from oil and gas wells. The tested scale contained more than $80 \%$ pyrite and they used $20 \mathrm{wt} . \%$ diethylenetriamine pentaacetic acid (DTPA) chelating agent at $\mathrm{pH} 11$ with $9 \mathrm{wt} . \%$ potassium carbonate as a catalyst. The DTPA formulation dissolved $85 \%$ of the scale at $70{ }^{\circ} \mathrm{C}$ for $48 \mathrm{~h}$. They suggested several catalysts that can enhance the dissolution rate of the pyrite scale such as potassium carbonate, cesium formate, and cesium carbonate. Abou Baker et al. [26] used a novel product that combines the effectiveness of chelating agent and dissolver of iron sulphide in actual field application (sandstone reservoir with a temperature of $149^{\circ} \mathrm{C}$ ). They concluded that the well production was returned with an increment of $50 \%$ above its original rate and the well was producing natural flow without using the jet pump.

Using less corrosive acids such as formic acid, thioglycolic acid, glyoxylic acid, or maleic acid can help in dissolving iron sulfide scales at high temperatures [19,27]. Acrolein (2-propenal) was claimed to be an iron sulfide scales dissolver and also acted as an $\mathrm{H}_{2} \mathrm{~S}$ scavenger and biocide [28,29]. However, acrolein should be carefully handled due to its high acute toxicity and also it is supposed to be a carcinogen [30]. Tetrakis (hydroxymethyl) phosphonium salts (THPS) as sulfate THPS showed a good dissolution performance for iron sulfide scale when it was injected with a small amount of alkylamine or it was preferred to use an ammonium salt [3,31]. During the removal of the iron sulfide scale, the iron was chelated to a nitrogen-phosphorus ligand and that made the water a red color. THPS was used successfully in a field application with a surfactant to kill sulfate-reducing bacteria SRB and dissolve iron sulfide scales, which led to $300 \%$ increase in the production rate in several wells [32]. Wang et al. [33] used THPS with different concentrations and additives to remove different iron sulfide scales consisting of pyrrhotite $\mathrm{Fe}_{7} \mathrm{~S}_{8}$, mackinawite $\mathrm{FeS}$, pyrite $\mathrm{FeS}_{2}$, marcasite $\mathrm{FeS}_{2}$, calcite, siderite, 
and anhydrite. They used different concentrations of THPS (from 15 to $75 \mathrm{wt.} \%$ ) and soaked it for time periods from 1-24 h. They also investigated the effect of ammonium chloride salt on the dissolution rate of scale and found that $50 \mathrm{wt} . \%$ THPS yielded the highest removal efficiency. The addition of ammonium chloride enhanced the scale solubility because it produced $\mathrm{HCl}$ but it increased the corrosion rate at $85^{\circ} \mathrm{C}$. However, THPS formulation with ammonium salts was found to be corrosive particularly at high-temperature conditions which makes it highly requiring a corrosion inhibitor [34].

Using THPS with EDTA as a chelating agent for removal of iron sulfide scale from a real field sample resulted in $70 \%$ solubility. The THPS and EDTA solution made had a neutral $\mathrm{pH}$ that would reduce the corrosion rate and consequently reduce the adding of corrosion inhibitors [35]. Hafiz et al. [36] reported a procedure to produce a synthetic iron sulfide scale with a multi-mineralogical composition similar to the scales commonly found in Khuff sour wells (26\% pyrite, $11 \%$ goethite, $29 \%$ elemental sulfur, $19 \%$ halite, $13 \%$ iron hydroxide sulfate, and $2 \%$ alpha iron sulfate). Three dissolver were tested to dissolve the synthetic iron sulfide scale sample; dissolver (A) containing functionalized polymers, dissolver (B) containing a blend of THPS, and dissolver (C) containing a 50:50 mixture of A and B. The three dissolver A, B, and C achieved a dissolving capacity of $8.12 \mathrm{~g} / \mathrm{L}, 3.5 \mathrm{~g} / \mathrm{L}$, and $38.8 \mathrm{gm} / \mathrm{L}$ respectively, which indicates a synergetic action of dissolvers $\mathrm{A}$ and $\mathrm{B}$.

Another approach to remove iron sulfide scales is by the conversion of the insoluble Fe(II) to soluble Fe(III) using oxidizing agents such as chlorites/chlorine dioxide or permanganates, but using oxidizing agents could cause corrosion $[37,38]$. Reducing the particle size of the scale will increase the surface area of scale particles, and therefore, increase the interactions between the scale and the dissolver. However, it was found that there was a limited effect on the dissolution rate by increasing volume ratio of the dissolver with the scale mass and increasing agitation under the test conditions [39]. Recent studies were performed to find an effective chemical solution for removing the precipitated iron sulfide scales, and improving the scale dissolution [40-42].

The understanding of the origin of iron, formation of the iron sulfides, and sulfidation processes for iron surfaces is very important for the chemical surface interactions and provides a key role for designing the removal of iron sulfide scale [43]. Recently, a work by Onawole et al. [44] provided a new way for designing green chelating agents for the chemical removal of iron sulfide scale. Another recent study was performed to determine the optimum treatment time and $\mathrm{pH}$ control for the chelating agent as a chemical dissolution for the iron sulfide [45]. Ahmed et al. [46] studied the combination of THPS with EDTA to provide a basic $\mathrm{pH}$ that would help to reduce the tubular corrosion rate and reduce the use of corrosion inhibitors. The experimental and computational analysis showed that using THPS with EDTA is effective in dissolving iron sulfide scales as pyrrhotite $\left(\mathrm{Fe}_{7} \mathrm{~S}_{8}\right)$ and troilite (FeS).

Based on the above literature, there is an urgent need for the development of an environmentally friendly stable chemical formulation for the removal of iron sulfide which can efficiently remove the iron sulfide scale while being non-corrosive to the equipment and not releasing $\mathrm{H}_{2} \mathrm{~S}$ gas after the reaction with iron sulfide scale. In this paper, a new environmentally friendly acid system for iron scale sulfide scale removal was evaluated using actual field samples.

\section{Materials and Experimental}

\subsection{Materials}

A real sample of iron sulfide scale from the field was obtained and the composition of the sample was determined using X-ray powder diffraction (XRD). The composition of the iron sulfide scale sample is listed in Table 1. The new environmentally friendly acid system used in this study is a green acid solution synthesized by a catalytic reagent combination added to $\mathrm{HCl}$, creating a biodegradable, non-bioaccumulating alternative to $\mathrm{HCl}$. The synthesis removes the exothermic reaction created when water is added to $\mathrm{HCl}$ and significantly increases the strength of the acid, simultaneously creating a cathodic stimulation reducing the corrosiveness by a factor of 50 at ambient temperature. The titration test was performed to determine the actual percentage of $\mathrm{HCl}$ existing in the developed system and it 
was found that the $100 \mathrm{wt} . \%$ NEFAS (New Environmentally Friendly Acid System) contains 20 wt.\% $\mathrm{HCl}$ in addition to other additives.

Table 1. XRD analysis of the scale field sample.

\begin{tabular}{ccc}
\hline Component & Chemical Formula & Percentage, \% \\
\hline Pyrrhotite & $\mathrm{Fe}_{7} \mathrm{~S}_{8}$ & 55 \\
Troilite & $\mathrm{FeS}$ & 6 \\
Mackinawite & $\mathrm{FeS}$ & 1 \\
Pyrite & $\mathrm{FeS}_{2}$ & 8 \\
Hibbingite & $\mathrm{Fe}(\mathrm{OH})_{3} \mathrm{Cl}$ & 2 \\
Siderite & $\mathrm{FeCO} 3$ & 3 \\
Geothite & $\mathrm{a}-\mathrm{FeOOH}$ & 1 \\
Akaganeite & $\beta-\mathrm{FeOOH}_{3}$ & 3 \\
Calcite & $\mathrm{CaCO}_{3}$ & 21 \\
\hline
\end{tabular}

Table 2 shows the fluid properties measured for the $100 \mathrm{wt} . \%$ and $75 \mathrm{wt} . \%$ NEFAS at room temperature. The $75 \mathrm{wt} . \%$ NEFAS had a density of $1.07 \mathrm{gm} / \mathrm{cm}^{3}$, a viscosity of $1.58 \mathrm{cP}$, the surface tension of $31.4 \mathrm{mN} / \mathrm{m}$, and a $\mathrm{pH}$ of 0.04 . Furthermore, commercial chemicals used in the real field application of iron sulfide scale removal were used also to compare their removal efficiency with NEFAS solution. The commercial chemicals used in the study were HDC-3, $20 \mathrm{wt} . \%$ GLDA, and 15 and $20 \mathrm{wt} . \%$ hydrochloric acid. GLDA was obtained from a service company at $40 \mathrm{wt} . \%$ stock concentration and $\mathrm{pH} 4$, while HDC-3 was obtained at a $\mathrm{pH}$ of 14 from another service company. Corrosion inhibitor based on amino acids such as 3,5-diiodotyrosine and corrosion intensifiers such as tetrahydro-3,5-dimethyl-2H-1,3,5-thiadiazine-2-thione were used.

Table 2. NEFAS(New Environmentally Friendly Acid System) (75 wt.\%) fluid properties at ambient temperature $25^{\circ} \mathrm{C}$.

\begin{tabular}{ccc}
\hline Fluid Property & 100 wt. $\%$ NEFAS & 75 wt. $\%$ NEFAS \\
\hline Density $\left(\mathrm{gm} / \mathrm{cm}^{3}\right)$ & 1.04 & 1.07 \\
Viscosity $(\mathrm{cP})$ & 1.46 & 1.58 \\
Surface Tension $(\mathrm{mN} / \mathrm{m})$ & 42.95 & 31.56 \\
$\mathrm{pH}$ & -1.29 & 0.04 \\
\hline
\end{tabular}

\subsection{Experimental Work}

\subsubsection{Solubility Test}

The solubility tests were executed for the iron scale sample using the hot plate at a temperature of $125^{\circ} \mathrm{C}$ and static condition. The solubility tests were conducted under a static condition to mimic the real field scale removal methodology during which the scale was soaked at static conditions for a certain soaking time to allow reaction between the acid and the scale in the well. The ratio of the scale weight to the removal fluid volume was decided as recommended by Bageri et al. [47,48] to design the solid to liquid ratio for the scale removal operation. That solid to liquid ratio depends on the amount of scale formed along the tubing internal diameter and so, the weight of the scale can be determined from the scale density and the accumulated scale volume that causes a decrease in the tubing internal diameter. Comparable work was performed by Elkatatny [49] to remove the iron sulfide scale using a new formulation and the author used a solid to liquid ratio (1:10) where $2 \mathrm{~g}$ of iron sulfide scale was soaked in $20 \mathrm{~g}$ of the removal fluid. He concluded that the acid mixture solubility was $78 \mathrm{~g} / \mathrm{L}$ of iron sulfide scale at $100^{\circ} \mathrm{C}$ after $24 \mathrm{~h}$. In this study, the solid to liquid ratio used was 1:10. A solution of NEFAS fluid $(20 \mathrm{~mL})$ with concentration $75 \mathrm{wt} . \%$ was prepared and heated up to $125^{\circ} \mathrm{C}$ using the hot plate connected to a liquid condenser to avoid any change in the liquid volume due to evaporation as shown in Figure 2. Then $2 \mathrm{~g}$ of the iron sulfide scale sample was added to the solution. The same 
procedures were repeated for different soaking times as 2, 6, 12, 24 h at a static condition to evaluate the fluid removal efficiency as a function of time.

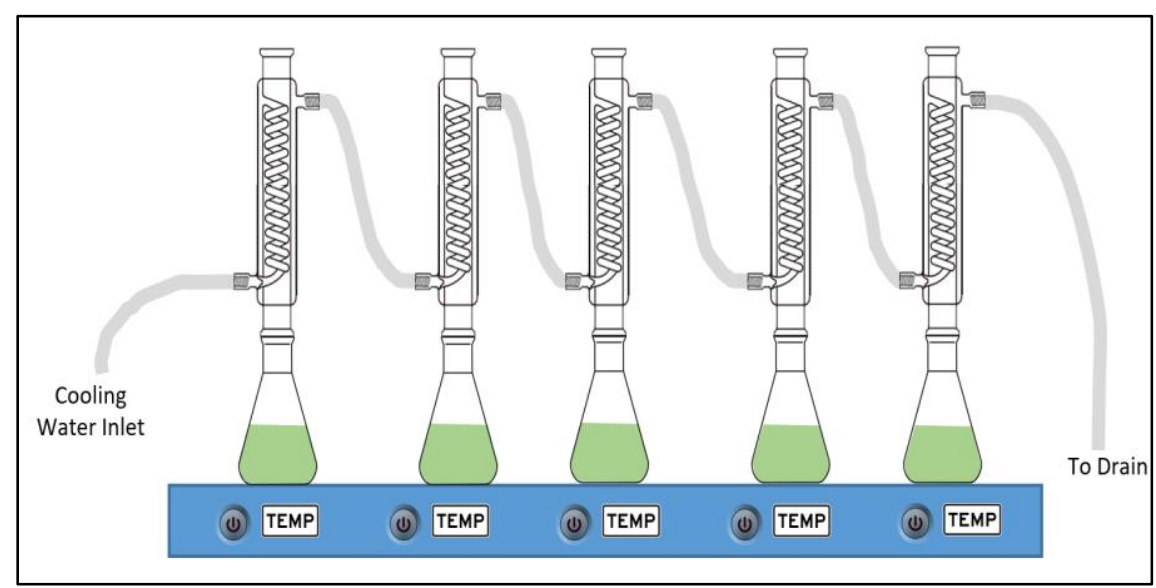

Figure 2. Multiple-position hot plate.

\subsubsection{Corrosion Test}

The corrosion test is usually performed to evaluate the corrosiveness of acids used in the oil and gas industry to ensure that it will not affect the integrity of the tubing and the downhole completion because of the high corrosion rate. It also ensures that the acid will not damage the surface equipment used to mix and inject the chemicals into wells or surface flowlines. The test measures the effect of the fluid on a steel coupon taken from coiled tubing material by calculating the corrosion rate after hanging the steel coupon in the fluid under $3.447 \mathrm{MPa}$ and $125^{\circ} \mathrm{C}$, using the high-pressure high-temperature aging cell shown in Figure 3. The aging cell is isolated by teflon body to protect the steel body of the cell from the corrosive fluids.

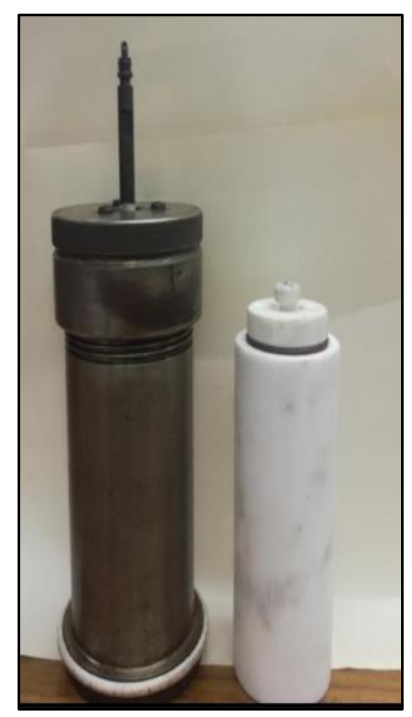

Figure 3. High-pressure aging cell and teflon liner used for the corrosion test.

The test procedures as follow:

1. An acid volume of $350 \mathrm{~mL}$ was prepared.

2. The weight, thickness, and curvature radius of the steel coupon were measured.

3. The steel coupon was hanged in the high-pressure high-temperature aging cell.

4. A teflon liner that can be placed inside the aging cell was filled with the $350 \mathrm{~mL}$ acid volume. 
5. The steel coupon was hanged in the teflon liner and ensured to be completely submerged in the fluid.

6. The teflon liner was placed inside the aging cell and the aging cell cap was closed.

7. A pressure of $3.447 \mathrm{MPa}$ was applied from the top valve of the aging cell using nitrogen gas.

8. The aging cell was placed inside the oven for $6 \mathrm{~h}$ under a temperature of $125^{\circ} \mathrm{C}$.

9. After $6 \mathrm{~h}$, the aging cell was taken out from the oven and waited until it cooled, then the pressure was vented and the cell was opened.

10. The measurements in step 2 were recorded again after the interaction with the fluid.

11. The corrosion rate was calculated.

The test was repeated following the same procedure to measure the corrosion rate for each acid system under the same conditions. For each test, a new coupon was used. The test was performed for the NEFAS fluid, $15 \mathrm{wt} . \% \mathrm{HCl}$ with adding $2 \mathrm{wt} . \%$ corrosion inhibitor (N, N-diallyl-N-benzyl dodecyl ammonium) and $2 \mathrm{wt} . \%$ corrosion intensifier (formic acid). Adding the corrosion inhibitor to the acid will help to protect the tubular from the corrosion effect at high-temperature conditions while the intensifiers are usually added to the corrosion inhibitor to extend its performance under conditions such as higher acid concentration, high temperature, and long-time operations [50,51].

\section{Results and Discussion}

The solubility experiments were performed for different concentrations of NEFAS (100 wt. $\%$ and $75 \mathrm{wt} . \%)$ and $\mathrm{HCl}(15 \mathrm{wt} . \%$ and $20 \mathrm{wt} . \%$ ) for $6 \mathrm{~h}$ for the initial comparison with $\mathrm{HCl}$. Figure 4 shows that the solubilities of the four solutions are very close to each other and the $75 \mathrm{wt} . \%$ NEFAS achieved $83 \mathrm{~g} / \mathrm{L}$ solubility of the iron sulfide while $100 \mathrm{wt} . \%$ NEFAS dissolved $82 \mathrm{~g} / \mathrm{L}$ after $6 \mathrm{~h}$. Therefore, The $75 \mathrm{wt} . \%$ NEFAS is more effective than the $100 \mathrm{wt} . \%$ NEFAS which will save $25 \%$ of the acid cost. Whenever the concentration of NEFAS was reduced below $75 \mathrm{wt} . \%$, no considerable solubilities were achieved. The lower dissolving power for the $100 \mathrm{wt} . \%$ NEFAS compared to $75 \mathrm{wt} . \%$ NEFAS can be a result of the reduced fluid activity caused by the retarding effects of the dissolved reaction products and the increased NEFAS viscosity. Similar trends were reported for GLDA and $\mathrm{HCl}$ when used to dissolve carbonate rocks $[52,53]$.

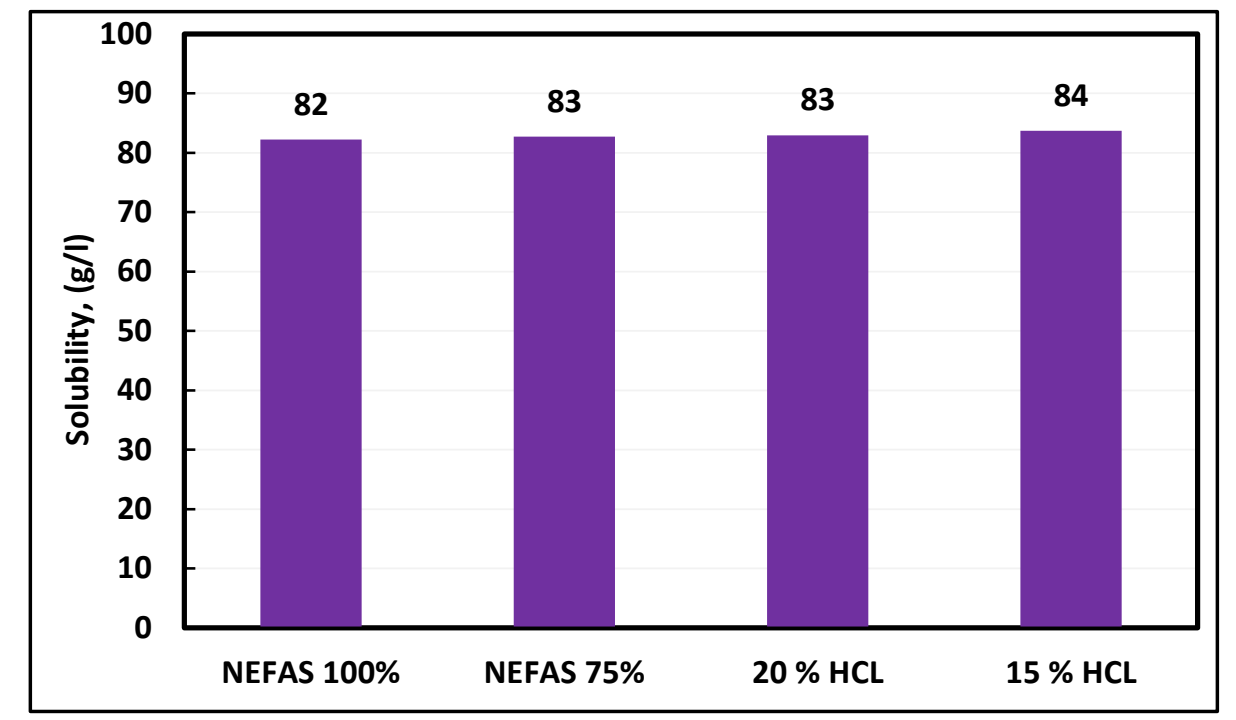

Figure 4. Static solubility of iron sulfide scale using different acid systems at $125^{\circ} \mathrm{C}$ for $6 \mathrm{~h}$.

The solubility of iron sulfide by $75 \%$ NEFAS under static conditions at different soaking times increased with soaking time for the first six hours as shown in Figure 5. The solubility of the iron sulfide after $2 \mathrm{~h}$ of soaking with NEFAS $75 \%$ was $77 \mathrm{~g} / \mathrm{L}$ and increased to reach $83 \mathrm{~g} / \mathrm{L}$ after $6 \mathrm{~h}$. No 
significant increase in the solubility can be noticed for soaking times of $12,18,20$, and $24 \mathrm{~h}$ compared to $6 \mathrm{~h}$. The obtained results confirmed that the NEFAS can be used with a concentration of $75 \mathrm{wt} . \%$ to remove the iron scale sample with high efficiency for only $6 \mathrm{~h}$.

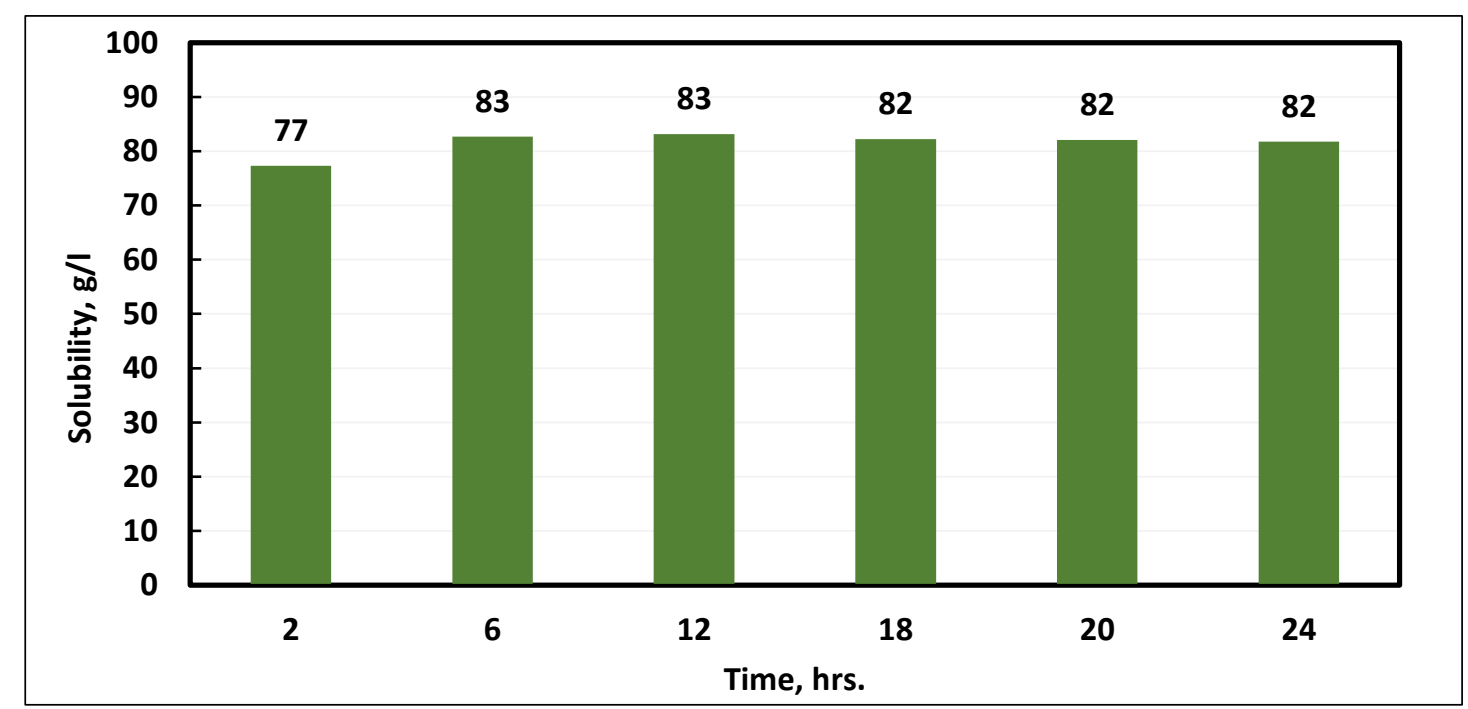

Figure 5. Static solubility of iron sulfide scale using $75 \mathrm{wt} . \%$ NEFAS at $125^{\circ} \mathrm{C}$.

Table 3 shows the solubility results of the iron sulfide scale using different acid systems commercially used in the oil field for scale dissolvers for 6 and $24 \mathrm{~h}$ at $125^{\circ} \mathrm{C}$. Figure 6 demonstrates that the solubility of HDC-3 was low (18 g/L) after $24 \mathrm{~h}$. While $20 \mathrm{wt} . \%$ GLDA at pH 4 has a moderate solubility of $65 \mathrm{~g} / \mathrm{L}$ after $24 \mathrm{~h}$. The $15 \mathrm{wt} . \% \mathrm{HCl}$ was able to remove the scale after $24 \mathrm{~h}$ with an efficiency of $84 \%$ while NEFAS was able to achieve the same solubility of 15 wt. $\% \mathrm{HCl}$ after only $6 \mathrm{~h}$. For further comparison, the corrosion tests were conducted for both NEFAS and $\mathrm{HCl}$.

Table 3. Static solubility results of iron sulfide scale using different chemicals and concentrations after 6 and $24 \mathrm{~h}$ at $125^{\circ} \mathrm{C}$.

\begin{tabular}{cccc}
\hline Removal Fluid & Time, (hr) & Solubility, (g/L) & Solubility, (\%) \\
\hline HDC-3 & 24 & 18 & 18 \\
GLDA (20 wt.\%) & 24 & 65 & 65 \\
NEFAS (75 wt.\%) & 24 & 82 & 82 \\
HCl (15 wt.\%) & 24 & 84 & 84 \\
NEFAS (100 wt.\%) & 6 & 82 & 82 \\
NEFAS (75 wt.\%) & 6 & 83 & 83 \\
HCl (20 wt.\%) & 6 & 83 & 83 \\
HCl (15 wt. $\%)$ & 6 & 84 & 84 \\
\hline
\end{tabular}

The corrosion tests were conducted using actual coiled tubing steel coupon soaked with $75 \mathrm{wt} . \%$ NEFAS and $15 \mathrm{wt} . \% \mathrm{HCl}$ for $6 \mathrm{~h}$ at $125^{\circ} \mathrm{C}$. Table 4 represents the corrosion test results for the two removal fluid systems NEFAS (75 wt.\%) and $\mathrm{HCl}(15 \mathrm{wt} . \%)$. Figure 7 shows that the corrosion rate of $15 \mathrm{wt} . \% \mathrm{HCl}$ was $0.808 \mathrm{~kg} / \mathrm{m}^{2}$, which is higher than the acceptable range by the oil and gas industry $\left(0.244 \mathrm{~kg} / \mathrm{m}^{2}\right.$ at $\left.125^{\circ} \mathrm{C}\right)$. The corrosion rate of $75 \mathrm{wt} . \%$ NEFAS was $0.211 \mathrm{~kg} / \mathrm{m}^{2}$ after adding the corrosion inhibitor CI ( $2 \mathrm{wt} . \%)$ and corrosion intensifier CIN ( $2 \mathrm{wt} . \%)$. Based on these results, NEFAS will not affect the integrity of wellbore tubular compared to the commonly used $\mathrm{HCl}$-based formulations in field applications. 


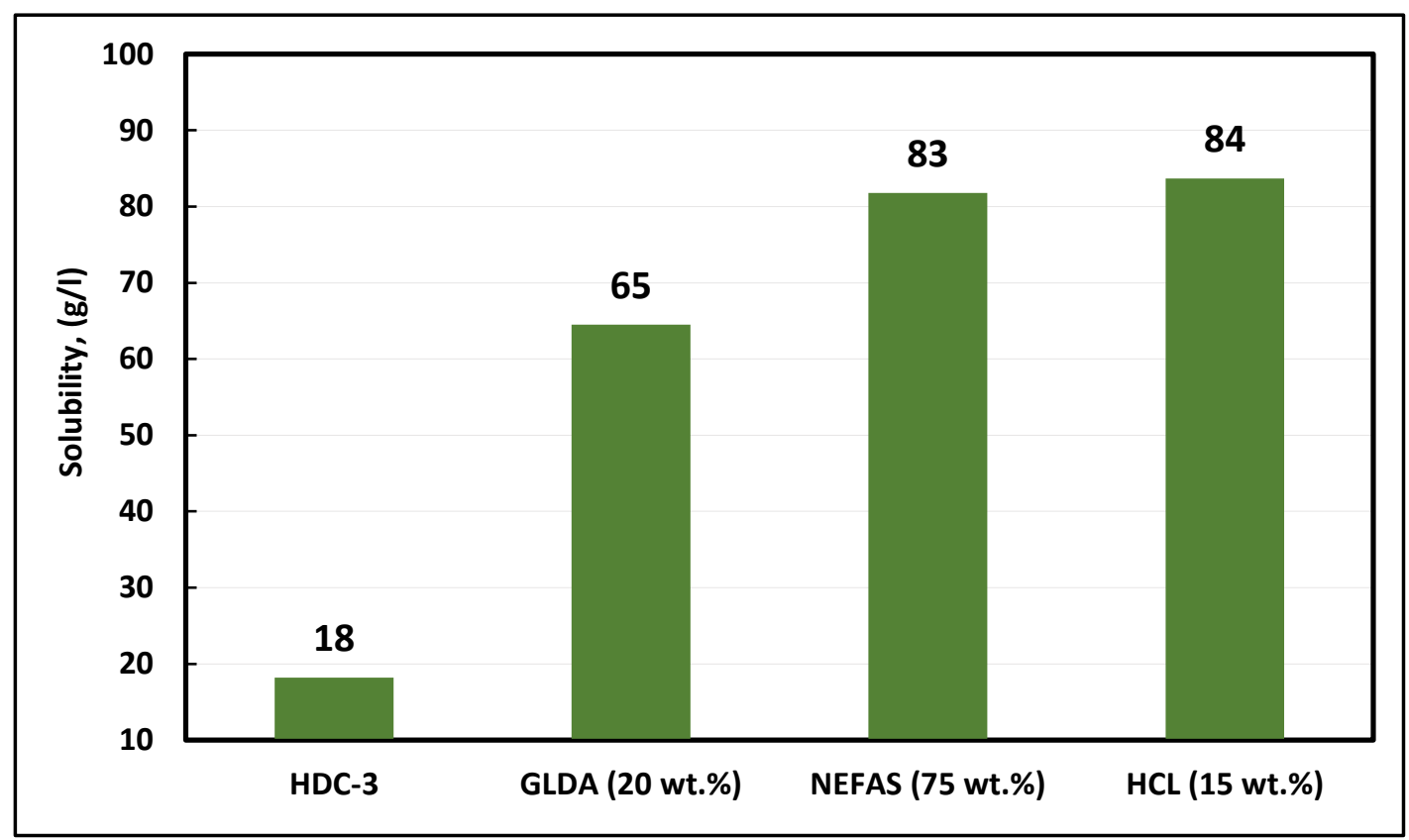

Figure 6. Static solubility of iron sulfide scale using different chemicals at $125^{\circ} \mathrm{C}$ for $24 \mathrm{~h}$.

Table 4. Corrosion test results at $125^{\circ} \mathrm{C}$ and $3.447 \mathrm{MPa}$.

\begin{tabular}{cccccc}
\hline \multirow{2}{*}{ Acid } & \multicolumn{2}{c}{ Coupon Weight, $(\mathbf{g})$} & \multicolumn{2}{c}{ Coupon Thickness, $(\mathbf{m m})$} & \multirow{2}{c}{$\begin{array}{c}\text { Corrosion } \\
\text { Rate, }\left(\mathbf{k g} / \mathbf{m}^{\mathbf{2}}\right)\end{array}$} \\
\cline { 2 - 4 } & Before & After & Before & After & \\
\hline $75 \%$ NEFAS + 2\% C.I. + 2\% Int. & 12.345 & 11.992 & 2.464 & 2.413 & 0.211 \\
$15 \%$ HCL + 2\% C.I. + 2\% Int. & 12.373 & 11.000 & 2.464 & 2.261 & 0.808 \\
$15 \%$ HCL & 12.118 & 2.697 & 2.464 & 1.245 & 0.244 \\
\hline
\end{tabular}

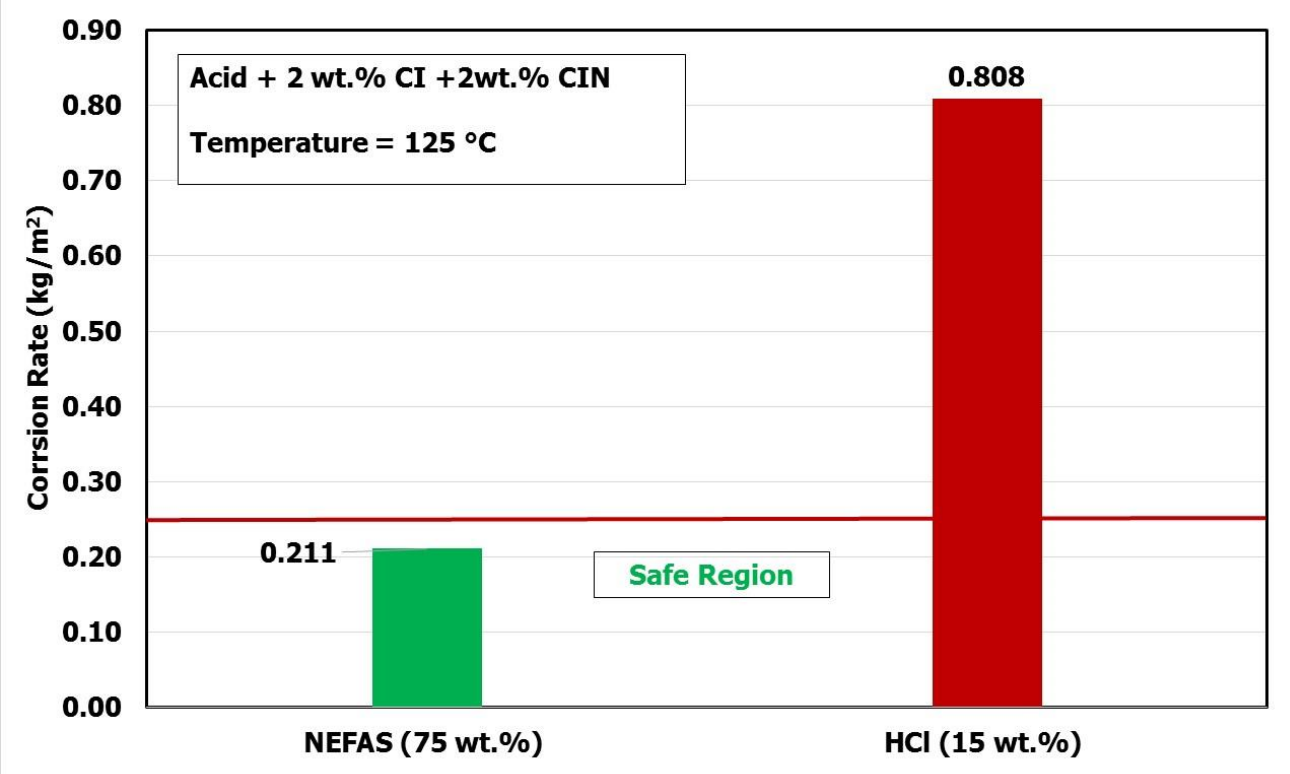

Figure 7. Corrosion rate comparison between NEFAS system (75 wt. $\%$ NEFAS + 2 wt. $\%$ CI + 2 wt. $\%$ $\mathrm{CIN}$ ) compared to $\mathrm{HCl}$ system ( 5 wt. $\% \mathrm{HCl}+$ with 2 wt. $\% \mathrm{CI}+2 \mathrm{wt} . \% \mathrm{CIN}$ ) at $125^{\circ} \mathrm{C}$ and $3.447 \mathrm{MPa}$. 


\section{Conclusions}

Extensive lab work was conducted to determine the removal efficiency of a new biodegradable acid system, NEFAS, for iron sulfide scale using actual field sample at $125^{\circ} \mathrm{C}$. Based on the obtained results, the following conclusions can be drawn:

1. NEFAS (75 wt.\%) achieved iron sulfide solubility of $(83 \mathrm{~g} / \mathrm{L})$ after $6 \mathrm{~h}$.

2. NEFAS (75 wt.\%) outperformed GLDA (20 wt.\%), HDC-3, and $\mathrm{HCl}(15 \mathrm{wt} . \%)$ for iron sulfide scale removal.

3. The corrosion rate for the NEFAS (75 wt. $\%$ ) was $0.211 \mathrm{~kg} / \mathrm{m}^{2}$ at $125^{\circ} \mathrm{C}$, which is lower than the corrosion rate accepted by the oil and gas industry after adding $2 \mathrm{wt} . \%$ corrosion inhibitor and 2 wt.\% corrosion intensifier.

Author Contributions: Conceptualization, S.E. and K.A.; Methodology, H.G.; Validation, H.G., K.A. and S.E.; Formal Analysis, K.A.; Investigation, S.E.; Resources, S.E.; Data Curation, H.G.; Writing-Original Draft Preparation, K.A., H.G.; Writing-Review \& Editing, S.E.; Visualization, K.A.; Supervision, S.E.

Funding: This research was funded by Enviroklean Product Development, Inc. (EPDI) and Maeen Companied Companies under grant number CIPR2324.

Acknowledgments: The authors wish to acknowledge King Fahd University of Petroleum and Minerals (KFUPM) for utilizing the various facilities to carry out this research. Special acknowledge to Enviroklean Product Development, Inc. (EPDI) and Maeen Companies for providing the acid system.

Conflicts of Interest: The author declares no conflict of interest.

\section{References}

1. Kasnick, M.A.; Engen, R.J. Iron Sulfide Scaling and Associated Corrosion in Saudi Arabian Khuff Gas Wells. Presenced at the SPE Middle East Oil Technical Conference and Exhibition, Manama, Bahrain, 11-14 March 1989. SPE-280-MS. [CrossRef]

2. Nasr-El-Din, H.A.; Fadhel, B.A.; Al-Humaidan, A.Y.; Frenier, W.W.; Hill, D. An Experimental Study of Removing Iron Sulfide Scale from Well Tubulars. Presenced at the International Symposium on Oilfield Scale, Aberdeen, UK, 26-27 January 2000. SPE-60205-MS. [CrossRef]

3. Chen, T.; Montgomerie, H.; Chen, P.; Hagen, T.H.; Kegg, S.J. Development of Environmental Friendly Iron Sulfide Inhibitors for Field Application. Presenced at the International Symposium on Oilfield Chemistry, The Woodlands, TX, USA, 20-22 April 2009. SPE-121456-MS. [CrossRef]

4. Nasr-El-Din, H.A.; Rosser, H.R.; Hopkins, J.A. Simulation of Injection Water Supply Wells in Central Arabia. Society of Petroleum Engineers. Presenced at the Abu Dhabi International Petroleum Exhibition and Conference, Abu Dhabi, United Arab Emirates, 13-16 October 1996. SPE-36181-MS. [CrossRef]

5. Nasr-El-Din, H.A.; Al-Humaidan, A.Y.; Mohamed, S.K.; Al-Salman, A.M. Iron Sulfide Formation in Water Supply Wells With Gas Lift. Presenced at the the SPE International Symposium on Oilfield Chemistry, Houston, TX, USA, 13-16 February 2001. SPE-65028-MS. [CrossRef]

6. Nasr-El-Din, H.A.; Al-Humaidan, A.Y. Iron Sulfide Scale: Formation, Removal, and Prevention. Presenced at the International Symposium on Oilfield Scale, Aberdeen, UK, 30-31 January 2001. SPE-68315-MS. [CrossRef]

7. Cord-Ruwisch, R.; Kleinitz, W.; Widdel, F. Sulfate-reducing Bacteria and Their Activities in Oil Production. J. Pet. Technol. 1987, 39, 97-106. [CrossRef]

8. Cusack, F.; McKinley, V.L.; Lappin-Scott, H.M.; Brown, D.R.; Clementz, D.M.; Costerton, J.W. Diagnosis and Removal of Microbial/Fines Plugging in Water Injection Wells. Presenced at the SPE Annual Technical Conference and Exhibition, Dallas, TX, USA, 27-30 September 1987. SPE-16907-MS. [CrossRef]

9. Taylor, K.C.; Nasr-El-Din, H.A.; Al-Alawi, M.J. Systematic Study of Iron Control Chemicals Used During Well Stimulation. SPE J. 1999, 4, 19-24. [CrossRef]

10. Wang, Q.; Ajwad, H.; Shafai, T.; Lynn, J.D. Iron Sulfide Scale Dissolvers: How Effective Are They? Presenced at the SPE Saudi Arabia Section Technical Symposium and Exhibition, Al-Khobar, Saudi Arabia, 19-22 May 2013. SPE-168063-MS. [CrossRef]

11. Kamal, M.S.; Hussein, I.; Mahmoud, M.; Sultan, A.S.; Saad, M.A. Oilfield scale formation and chemical removal: A review. J. Pet. Sci. Eng. 2018, 171, 127-139. [CrossRef] 
12. Seto, C.J.; Beliveau, D.A. Reservoir Souring in the Caroline Field. Presenced at the SPE/CERI Gas Technology Symposium, Calgary, AB, Canada, 3-5 April 2000. SPE-59778-MS. [CrossRef]

13. Hall, B.E.; Dill, W.R. Iron Control Additives for Limestone and Sandstone Acidizing of Sweet and Sour Wells. Presenced at the SPE Formation Damage Control Symposium, Bakersfield, CA, USA, 8-9 February 1988. SPE-17157-MS. [CrossRef]

14. Crowe, C.W. Evaluation of Agents for Preventing Precipitation of Ferric Hydroxide from Spent Treating Acid. J. Pet. Technol. 1958, 37, 691-695. [CrossRef]

15. Crowe, C.W. Prevention of Undesirable Precipitates from Acid Treating Fluids. Presenced at the International Meeting on Petroleum Engineering, Beijing, China, 17-20 March 1986. SPE-14090-MS. [CrossRef]

16. Sherik, A.M.; Zaidi, S.R.; Tuzan, E.V.; Perez, J.P. Black powder in gas transmission systems. Presenced at the NACE International Source CORROSION 2, New Orleans, LA, USA, 16-20 March 2008. NACE-08415.

17. Ford, W.G.F.; Walker, M.L.; Halterman, M.P.; Parker, D.L.; Brawley, D.G.; Fulton, R.G. Removing a Typical Iron Sulfide Scale: The Scientific Approach. Presenced at the SPE Rocky Mountain Regional Meeting, Casper, WY, USA, 18-21 May 1992. SPE-24327-MS. [CrossRef]

18. Leal Jauregui, J.A.; Solares, J.R.; Nasr-El-Din, H.A.; Franco, C.A.; Garzon, F.O.; Al-Marri, H.M.; Al-Aqeel, S.A.; Izquierdo, G.A. A Systematic Approach to Remove Iron Sulphide Scale: A Case History. Society of Petroleum Engineers. Presenced at the Middle East Oil and Gas Show and Conference, Manama, Bahrain, 11-14 March 2007. SPE-105607-MS. [CrossRef]

19. Lawson, M.B. Method for Removing Iron Sulfide Scale From Metal Surfaces. U.S. Patent No. 4,351,673, 28 September 1982.

20. Nasr-El-Din, H.A.; Al-Humaidan, A.Y.; Fadhel, B.A.; Saleh, R. Effect of Acid Additives on the Efficiency of Dissolving Iron Sulfide Scale. Presenced at the NACE International, Orlando, FL, USA, 26-31 March 2000. NACE-00439.

21. Miller, R. Iron Sulfide Clean-Up Composition and Method. U.S. Patent No. 6,887,840, 3 May 2005.

22. Frenier, W.W.; Coffey, M.D.; Huffnes, J.D.; Smith, D.C. Method and Composition for Removing Sulfide-Containing Scale from Metal Surfaces. U.S. Patent No. 4,220,550, 2 September 1980.

23. Kelland, M.A. Production Chemicals for the Oil and gas Industry; CRC Press Taylor \& Francis Group: Manchester, UK; Boca Raton FL, USA, 2014.

24. Mahmoud, M.A.; Ba Geri, B.; Kamal, M.S.; Hussien, I.A. Removal of Pyrite and Different Types of Iron Sulfide Scales in Oil and Gas Wells without $\mathrm{H}_{2} \mathrm{~S}$ Generation. Presenced at the International Petroleum Technology Conference, Doha, Qatar, 7-9 December 2015. IPTC-18279-MS. [CrossRef]

25. Mahmoud, M.; Hussein, I.A.; Sultan, A.; Saad, M.A.; Buijs, W.; Vlugt, T.J. Development of efficient formulation for the removal of iron sulphide scale in sour production wells. Can. J. Chem. Eng. 2018, 96, 2526-2533. [CrossRef]

26. Abou Bakr, M.; Ibrahim, A.F.; Nasr-El-Din, H.; Abd El-Hay, A.; Amin, E. Removal of Iron Sulphide Scale with a New Formulation: A Field Application in a Sandstone Reservoir in Egypt. Presenced at the SPE Annual Technical Conference and Exhibition, Dallas, TX, USA, 24-26 September 2018. [CrossRef]

27. Zaid, G.H.; Wolf, B.A. Compositions and Methods for Controlling Downhole suLfide Deposits. U.S. Patent 6,774,090, 10 August 2004.

28. Jorda, R.M. Aqualin Biocide in Injection Waters. Presenced at the SPE Production Research Symposium, Tulsa, OK, USA, 12-13 April 1962. SPE-280-MS. [CrossRef]

29. Salma, T. Cost Effective Removal of Iron Sulfide and Hydrogen Sulfide from Water Using Acrolein. Society of Petroleum Engineers. Presenced at the Permian Basin Oil and Gas Recovery Conference, Midland, TX, USA, 21-23 March 2000. SPE-59708-MS. [CrossRef]

30. Wang, H.T.; Hu, Y.; Tong, D.; Huang, J.; Gu, L.; Wu, X.R.; Chung, F.L.; Li, G.M.; Tang, M.S. Effect of carcinogenic acrolein on DNA repair and mutagenic susceptibility. J. Biol. Chem. 2012, 287, 12379-12386. [CrossRef] [PubMed]

31. Nasr-El-Din, H.A.; Chesson, J.B.; Al-Mohammed, A.M. A New Chemical Treatment to Remove Multiple Damages in a Water Supply Well. Presenced at the European Formation Damage Conference, Sheveningen, The Netherlands, 25-27 May 2005. SPE-95001-MS. [CrossRef]

32. Rincon, P.R.; McKee, J.P.; Tarazon, C.E.; Guevara, L.A. Biocide Stimulation in Oil Wells for Downhole Corrosion Control and Increasing Production. Presenced at the International Symposium on Oilfield Corrosion, Aberdeen, UK, 28 May 2004. SPE-87562-MS. [CrossRef] 
33. Wang, Q.; Shen, S.; Badairy, H.; Shafai, T.; Jeshi, Y.; Chen, T.; Chang, F.F. Laboratory assessment of tetrakis (hydroxymethyl) phosphonium sulfate as dissolver for scales formed in sour gas wells. Int. J. Corros. Scale Inhib. 2015, 4, 235-254. [CrossRef]

34. Talbot, R.E.; Grech, J.M. Formulation for Corrosion and Scale Inhibition. International (PCT) Patent Application WO/2005/040050, 6 May 2005.

35. Onawole, A.T.; Hussein, I.A.; Saad, M.A.; Mahmoud, M.; Ahmed, M.E.; Nimir, H.I. Effect of pH on acidic and basic chelating agents used in the removal of iron sulfide scales: A computational study. J. Pet. Sci. Eng. 2019, 178, 649-654. [CrossRef]

36. Hafiz, T.; Hoegerl, M.; AlSuwaij, A.; Almathami, A. Synthetic Iron Sulfide Scale and Polymeric Scale Dissolvers. Presenced at the SPE Middle East Oil \& Gas Show and Conference, Manama, Bahrain, 6-9 March 2017. [CrossRef]

37. McCafferty, J.F.; Tate, E.W.; Williams, D.A. Field Performance in the Practical Application of Chlorine Dioxide as a Stimulation Enhancement Fluid. SPE Prod. Facil. 1993, 8, 9-14. [CrossRef]

38. Romaine, J.; Strawser, T.G.; Knippers, M.L. Application of Chlorine Dioxide as an Oilfield Facilities Treatment Fluid. SPE Prod. Facil. 1996, 11, 18-21. [CrossRef]

39. Aljeban, N.; Chen, T.; Balharth, S. Kinetics Study of Iron Sulfide Scale Dissolution. Society of Petroleum Engineers. Presenced at the Abu Dhabi International Petroleum Exhibition and Conference, Dhabi, United Arab Emirates, 12-15 November 2018. SPE-192675-MS. [CrossRef]

40. Chen, T.; Wang, Q.; Chang, F.; Aljeaban, N. Recent Development and Remaining Challenges of Iron Sulfide Scale Mitigation in Sour Gas Wells. Presenced at the International Petroleum Technology Conference, Beijing, China, 26-28 March 2019. IPTC-19315-MS. [CrossRef]

41. Ramanathan, R.; Nasr-El-Din, H. Improving the Dissolution of Iron Sulfide by Blending Chelating Agents and its Synergists. Presenced at the SPE Middle East Oil and Gas Show and Conference, Manama, Bahrain, 18-21 March 2019. SPE-195128-MS. [CrossRef]

42. Ko, S.; Wang, X.; Kan, A.T.; Tomson, M.B. Identification of Novel Chemicals for Iron Sulfide Scale Control and Understanding of Scale Controlling Mechanism. Presenced at the SPE International Conference on Oilfield Chemistry, Galveston, TX, USA, 8-9 April 2019. SPE-193550-MS. [CrossRef]

43. El Menjra, A.I.; Seyeux, A.; Mercier, D.; Beech, I.; Makama, Z.; Marcus, P. ToF-SIMS analysis of abiotic and biotic iron sulfide layers formed in aqueous conditions on iron surfaces. Appl. Surf. Sci. 2019, 484, 876-883. [CrossRef]

44. Onawole, A.T.; Hussein, I.A.; Sultan, A.; Abdel-Azeim, S.; Mahmoud, M.; Saad, M.A. Molecular and electronic structure elucidation of $\mathrm{Fe}^{2+} / \mathrm{Fe}^{3+}$ complexed chelators used in iron sulphide scale removal in oil and gas wells. Can. J. Chem. Eng. 2019, 97, 2021-2027. [CrossRef]

45. Ramanathan, R.; Nasr-El-Din, H. November. Evaluation of Chelating Agents for Iron Sulfide FeS Scale Removal. Presenced at the Abu Dhabi International Petroleum Exhibition \& Conference, Abu Dhabi, UAE, 11-14 November 2019. SPE-197891-MS. [CrossRef]

46. Ahmed, M.; Onawole, A.; Hussien, I.; Saad, M.; Mahmoud, M.; Nimir, H. March. Effect of pH on Dissolution of Iron Sulfide Scales Using THPS. Presenced at the SPE International Conference on Oilfield Chemistry, Galveston, TX, USA, 8-9 April 2019. SPE-193573-MS. [CrossRef]

47. Bageri, B.S.; Mahmoud, M.A.; Shawabkeh, R.A.; Al-Mutairi, S.H.; Abdulraheem, A. Filter Cake Porosity and Permeability Profile Along the Horizontal Well and Their Impact on Filter Cake Removal. Presenced at the International Petroleum Technology Conference, Doha, Qatar, 6-9 December 2015. IPTC-18465-MS. [CrossRef]

48. Bageri, B.S.; Mahmoud, M.A.; Shawabkeh, R.A.; Al-Mutairi, S.H.; Abdulraheem, A. Toward a Complete Removal of Barite (Barium Sulfate Barium Sulfate $\mathrm{BaSO}_{4}$ ) Scale Using Chelating Agents and Catalysts. Arab. J. Sci. Eng. 2017, 42, 1667-1674. [CrossRef]

49. Elkatatny, S. New Formulation for Iron Sulfide Scale Removal. Presenced at the Middle East Oil and Gas Show and Conference, Manama, Bahrain, 6-9 March 2017. SPE-183914-MS. [CrossRef]

50. Syafii, I.; Pandya, N.; Sabhapondit, A.; Hajj, H.E. High-Temperature Acidizing: Advantages of Inhibitor-Intensifier Synergy. Presenced at the Abu Dhabi International Petroleum Exhibition \& Conference, Abu Dhabi, UAE, 7-10 November 2016. SPE-183034-MS. [CrossRef] 
51. Brezinski, M.M. New Environmental Options for Corrosion Inhibitor Intensifiers. Presenced at the SPE/EPA Exploration and Production Environmental Conference, Austin, TX, USA, 1-3 March 1999. SPE-52707-MS. [CrossRef]

52. Mahmoud, M.A.; Nasr-El-Din, H.A.; De Wolf, C.; LePage, J.N. Stimulation of Carbonate Reservoirs Using GLDA (Chelating Agent) Solutions. Presenced at the SPE 132286-MS presented at the Trinidad and Tobago Energy Resources Conference, Port of Spain, Trinidad and Tobago, 27-30 June 2010. [CrossRef]

53. Mostofizadeh, B.; Economides, M.J. Optimum Injection Rate from Radial Acidizing Experiments. Presenced at the SPE Annual Technical Conference and Exhibition, New Orleans, LA, USA, 25-28 September 1994. SPE-28547-MS.

(C) 2019 by the authors. Licensee MDPI, Basel, Switzerland. This article is an open access article distributed under the terms and conditions of the Creative Commons Attribution (CC BY) license (http://creativecommons.org/licenses/by/4.0/). 